\title{
RESPON MASYARAKAT TERHADAP \\ MADRASAH DINIYAH DI KOTA PALU Community Response to Madrasah Diniyah in Palu City
}

\author{
Oleh: Rosdiana*
}

* Peneliti Pada Balai Penelitian dan Pengembangan Agama Makassar

J1. A.P. Pettarani No.72 Makassar

E-mail: $\underline{\text { rose-1\&g).yahoe.com }}$

\begin{abstract}
Abstrak
Penelitian ini berupaya untuk mengetahui respon masyarakat terhadap penyelenggaraan madrasah diniyah. Respon dimaksud pengetahuan, sikap dan prilaku masyarakat berkaitan dengan madrasah diniyah dan untuk mengetahui faktor-faktor yang mempengaruhi respon masyarakat terhadap penyelenggaraan madrasah diniyah. Hasil penelitian menunjukkan bahwa madrasah diniyah dominan diketahui oleh responden, namun beberapa hal berkaitan aspekyang mendukungpembelajaran madrasah diniyah belum diketahui oleh masyarakat seperti kurikidum, penjenjangan di madrasah diniyah, dan aspek legalistas ijazah. Demikian halnya pada aspek sikap dan prilaku responden terhadap madrasah diniyah meski sudah menunjukkan partisipasi yang tinggi namun beberapa aspek masih belum menunjukkan keterlibatan aktif dari responden. Beberapa sumber informasi responden berkaitan madrasah diniyah belum memberikan informasi maksiamal dan mendalam terhadap madrasah diniyah.
\end{abstract}

Kata Kunci: respon, masyarakat, madrasah diniyah

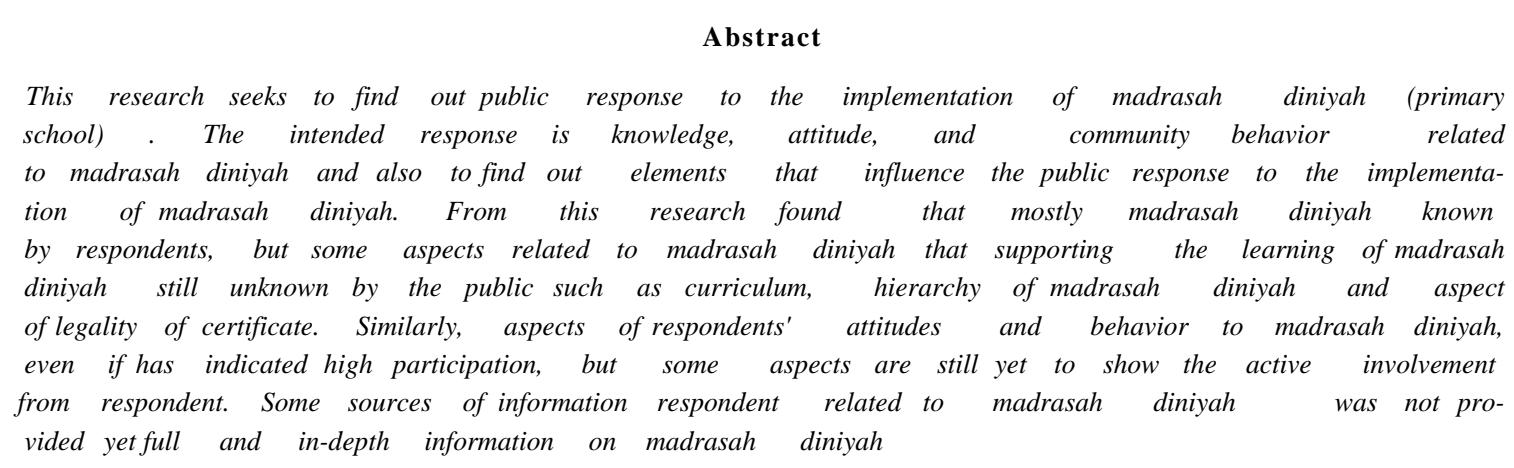

Key Words: response, communities, madrasah diniyah.

\section{PEN D A H U L U A N}

$\mathrm{M}$ adrasah Diniyah sebagai lcmbaga pendidikan Islam telah berdiri bersamaan dengan penyebaran agama Islam di Indonesia. Pengajaran dan pendidikan agama Islam timbul secara alamiah melalui proses akulturasi yang berjalan secara halus, perlahan dan damai sesuai dengan kebutuhan masyarakat sekitar. Dalam peningkatan kualitas madrasah diniyah diupayakan di antaranya dengan Permen Agama Nomor 3 Tahun 1983 tentang Kurikulum Madrasah Diniyah yang bertujuan untuk meningkatkan mutu pendidikan, schingga cita-cita pendidikan di madrasah diniyah dapat dicapai secara selektif. Selanjutnya UU No. 20 Tahun 2003 tentang Sistem Pendidikan Nasional yang dilanjutkan dengan disahkannyaPP Nomor 25 tentang Pendidikan Agama dan Pendidikan Keagamaan memperlihatkan sebuah perkembangan yang baik terhadap madrasah diniyah. Selain itu upaya pemerintah yang akan menyesuaikan kurikulum pendidikan madrasah diniyah dengan kurikulum nasional. Penyesuaian itu dilakukan sebagai upaya menyelaraskan pola pendidikan di madrasah diniyah dengan sistem pendidikan nasional. Karena itu, terdapat perubahan kualitas target pencapaian dari proses pendidikan di madrasah diniyah.

Dirjen Kelembagaan Agama Islam. Direktorat Pendidikan Keagamaan dan Pondok Pesantren. Departemen Agama RI, 2004, Pelimjuk Teknis Pondok Pesantren

]$^{\wedge}$ 
Sebagai lembaga pendidikan yang tumbuh dari -at. madrasah diniyah berjalan sesuai dengan keanampuan para pengasuh dan masyarakat - Nungnya, sehingga penyelenggaraan madrasah diniyah sangat beragam. Selaras dengan upaya -jaian pola pendidikan madrasah diniyah .- .." »istem pendidikan nasional di atas tampak an tidak memberikan perubahan pada minat - asyarakat terhadap pendidikan agama, dalam hal ini - Jiirasah diniyah.

Kajian terhadap madrasah diniyah sebagai sebuah rendidikan dominan diamati dari aspek proses dan output, sedangkan dari aspek input sangatjarang ii-akukan. Mengamati perkembangan minat dan respon - asyarakat tersebut terhadap madrasah diniyah, sangat urgen untuk dilakukan.

Penelitian ini bertujuan untuk mengetahui respon - asyarakat terhadap penyelenggaraan madrasah diniyah. Respon yang dimaksud terdiri atas pengetahuan. sikap dan prilaku masyarakat selama ini berkaitan dengan madrasah diniyah dan untuk -engetahui faktor-faktor yang mempengaruhi tingkat respon masyarakat terhadap penyelenggaraan - adrasah diniyah.

Jenis penelitian ini adalah deskriptif kuantitatif, populasi adalah masyarakat yang memiliki anak yang -zlah disekolahkan padajenjang pendidikan dasar dan - enengah (sederajat dengan SD/MI/MDA, SMP/ '•!7> MDW, dan SMA/MA/MDU), yang bermukim ;:>ekitar madrasah diniyah yang dijadikan sasaran anatan. Penarikan sampel dilakukan dengan dua tar.ap. yaitu purposif dan random. Penarikan sampel secara purposifdilakukan pada penentuan kabupaten/ ; la. dan madarsah diniyah yang akan dijadikan sebagai ^asaran penilaian. Sedangkan penarikan sampel secara -andom dilakukan dengan memilih sejumlah tertentu -.asyarakat yang memiliki anak yang disekolahkan rada jenjang pendidikan dasar dan menengah erajat dengan SD/MI/MDA, SMP/MTs/MDW, dan SMA/MA/MDU).

Data yang terkumpul melalui angkat/quesioner ::analisis secara deskritif kuantitatif dengan meng- akan jenis analisis pemusatan untuk mengetahui - ecendrungan minat dan respon masyarakat terhadap renvelenggaraan madrasah diniyah. Demikian halnya dengan menggunakanjenis analisis inferensial untuk mengetahui tingkat hubungan antar variabel sesuai kerangka analisis dengan menggunakan program SPSS. Sedangkan data atau informasi yang diperoleh dengan menggunakan wawancara, studi pustaka dan dokumentasi akan dianalisis secara kualitatif dengan proses klasifikasi, reduksi kemudian penarikan kesimpulan berupa fakta penelitian.

\section{TINJAUAN PUSTAKA}

\section{Pengertian Respon}

Respon berasal dari kata response, yang berarti jawaban, balasan atau tanggapan (reaction) Dalam Kamus Besar Bahasa Indonesia edisi ketiga dijelaskan definisi respon adalah berupa tanggapan, reaksi dan jawaban.

Respon adalah istilah yang digunakan oleh psikologi untuk menamakan reaksi terhadap rangsang yang diterima oleh panca indera. Respon biasanya diwujudkan dalam bentuk perilaku yang dimunculkan setelah dilakukan perangsangan.

Teori Behaviorisme menggunakan istilah respon yang dipasangkan dengan nakan adanya rangsang dari lingkungan. Jika rangsang dan respon dipasangkan atau dikondisikan maka akan membentuk tingkah laku baru terhadap rangsang'yang dikondisikan. ${ }^{2}$

Menurut Thorndike, respon adalah reaksi yang dimunculkan dapat berupa pikiran, perasaan, atau gerakan/tindakan. Jadi perubahan tingkah laku dapat terwujud konkret, yaitu yang dapat diamati, atau tidak konkret yaitu yang tidak dapat diamati. Teori Thorndike ini disebut pula dengan teori koneksionisme (Slavin, 2000). ${ }^{3}$

\section{Madrasah Diniyah}

Lembaga pendidikan Islam yang dikenal dengan madrasah, telah lama diselenggarakan di Indonesia. Kemunculan madrasah dipandang oleh sejarahwan pendidikan sebagai salah satu bentuk pembauran pendidikan Islam di Indonesia. Lembaga pendidikan ini telah ada bersamaan dengan penyebaran agama Islam di Indonesia." Setelah Indonesia merdeka dan setelah berdirinya Kementerian Agama, penyelenggaraan madrasah mendapat subsidi dan bimbingan dari Kementerian Agama. Tetapi pendirian madrasah

\footnotetext{
http://id.wikrpedia.org/wiki/Respon, diakses, 04 April 2010

' http://id.wikipedia.org/wiki/Teori_Belajar_Behavioristik, diakses, 04 April 2010

' Mahmud Arif. 2008. Pendidikan Islam Transformatif. Yogyakarta. LKiS. hal. 200
} 
diniyah mempunyai latar belakang tersendiri dan kebanyakan didirikan atas nama perorangan yang semata-mata untuk ibadah, maka sistem yang digunakan tergantung kepada latar belakang pendiri dan pengasuhnya, sehingga madrasah diniyah di Indonesia mengalami banyak ragam dan coraknya.

Sejalan dengan munculnya ide-ide pembaharuan pendidikan di Indonesia, dunia madrasah pun ikut mengadakan pembaharuan dari dalam. Beberapa organisasi pendidikan yang menyelenggarakan madrasah mulai menyusun kurikulum yang di dalamnya sudah terdapat mata pelajaran umum. Sementara itu pula pendirian madrasah negeri yang diasuh oleh Departemen Agama dengan memasukkan pendidikan umum, banyak memberikan pengaruh terhadap madrasah diniyah sehingga banyak menyesuaikan diri dengan kurikulum madrasah negeri tersebut."

Sehubungan dengan perkembangan madrasah diniyah yang demikian itu, maka untuk memudahkan pembinaan dan bimbingan, Departemen Agama menetapkan beberapa peraturan tentang jenis madrasah diniyah diatur dalam Peraturan Menteri AgamaRINomor BTahun 1964antaralaindijelaskan:

a. Madrasah diniyah ialah lembaga pendidikan yang memberikan pendidikan dan pengajaran secara klasikal dalam pengetahuan agama Islam kepada pelajar bersama-sama sedikitnya sepuluh orang atau lebih, diantara anak-anak berusia tujuh sampai dengan delapan belas tahun.

b. Pendidikan dan pengajaran pada madrasah diniyah selain bertujuan untuk memberi tambahan pengetahuan agama kepada pelajar-pelajar yang merasa kurang menerima pelajaran agama di sekolah-sekolah umum.

c. Madrasah diniyah memiliki tigatingkatan, yakni: Diniyah Awaliyah, Diniyah Wustha, dan Diniyah Ulya.

Madrasah diniyah juga telah memberikan kontribusi yang besar terhadap keikutsertaannya menjaga kelanjutan pendidikan keagamaan yang akhirakhir ini dirasakan oleh sebagian masyarakat, sedang terpuruk dengan indikasi berlarut-larutnya krisis moral bangsa ini.
Madrasah diniyah atau pendidikan diniyah merupakan salah satu bentuk pendidikan luar sekolah, berupa wajah dengan dua bentuk, yaitu pendidikan diniyah formal dan pendidikan diniyah non formal. Kurikulum pendidikan diniyah dasar formal wajib memasukkan muatan pendidikan kewarganegaraan, bahasa Indonesia, matematika, dan ilmu pengetahuan alam dalam rangkapelaksanaan program wajib belajar. Kurikulum pendidikan diniyah menengah formal wajib memasukkan muatan pendidikan kewarganegaraan, bahasa Indonesia, matematika, ilmu pengetahuan alam, serta seni dan budaya.

Sedangkan pendidikan diniyah nonformal merupakan pendidikan keagamaan Islam yang diselenggarakan dalam bentuk pengajian kitab, Majelis Taklim, Pendidikan Alquran, Diniyah Takmiliyah, atau bentuk lain yang sejenis. Pengajian kitab diselenggarakan dalam rangka mendalami ajaran Islam dan/ atau menjadi ahli ilmu agama Islam, yang dapat dilaksanakan secara berjenjang atau tidak berjenjang baik di pondok pesantren, masjid, mushalla, atau tempat lain yang memenuhi syarat. Majelis Taklim atau nama lain yang sejenis bertujuan untuk meningkatkan keimanan dan ketakwaan kepada Allah SWT dan akhlak mulia peserta didik serta mewujudkan rahmat bagi alam semesta, yang kurikulumnya bersifat terbuka dengan mengacu pada pemahaman terhadap Alquran dan Hadits sebagai dasar untuk meningkatkan keimanan dan ketakwaan kepada Allah SWT, serta akhlak mul ia dan dilaksanakan di masj id, mushalla, atau tempat lain yang memenuhi syarat. Pendidikan Alquran bertujuan meningkatkan kemampuan peserta didik membaca, menulis, memahami, dan mengamalkan kandungan Alquran, yang terdiri dari Taman KanakKanak Al-Qur'an (TKQ), Taman Pendidikan AlQur'an (TPQ), Ta'limul Qur'an lil Aulad (TQA), dan bentuk lain yang sejenis dan dapat dilaksanakan secara berjenjang dan tidak berjenjang, baik dipusatkan di masjid, mushalla, atau di tempat lain yang memenuhi syarat. Kurikulum pendidikan Alquran adalah membaca, menulis dan menghafal ayat-ayat Alquran, tajwid, serta menghafal doa-doa utama.' Sedangkan diniyah takmiliyah bertujuan untuk melengkapi pendidikan agama Islam yang diperoleh di SD/MI, SMP/MTs, SMA/MA, SMK/

Dirjen Kelembagaan Agama Islam, Direktorat Pendidikan Keagamaan dan Pondok Pesantren. Departemen Agama RI. 2004. Petunjuk Teknis Pondok Pesantren.

Abd. Azis Al Boneh. 2007. Studi Kompetensi Guru Madrasah Diniyah Ula di Kabupaten Agam Sumatera Barat. Jurnal Edukasi. Badan Litbang dan Diklat Depag RI. Volume 5 No. 4 Oktober - Desember 2007, h. 170

PP Nomor 25 Tahun 2007 tentane Pendidikan Agama dan Pendidikan Keagamaan. 
$K$ atau di pendidikan tinggi dalam rangka -gkatan keimanan dan ketakwaan peserta didik - faAllah SWT, yang penyelenggaraannya dapat tsanakan secara berjenjang atau tidak berjenjang,

: ixsanakan di masjid, mushalla, atau di tempat jo^imemenuhi syarat. Penyelenggaraan diniyah

- iapat dilaksanakan secaraterpadu dengan

SMP/MTs, SMA/MA, SMK/MAK atau : -iikan tinggi. ${ }^{8}$

\section{MB A H A S A N}

\section{idisi Madrasah Diniyah di Kota Palu}

Keberadaan madrasah diniyah di provinsi Sulawesi Bah sangat memberikan dampak yang positif dalam - njang aspek perkembangan pendidikan. Perran dari madrasah diniyah pada masing-masing - gdapat dilihat pada tabel 2 dan 3.

Tabel 2.

Jumlah Madrasah Diniyah Tingkat Kabupaten

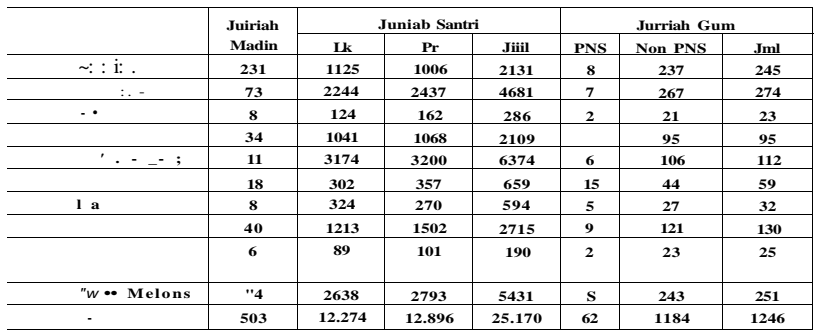

$$
\begin{array}{cccc}
\text {. :>er Data: Kementerian Agama Provinsi } \\
\text { Sulteng } 2010 & &
\end{array}
$$

Tabel 3.

Jumlah Madrasah Diniyah di Kota Palu

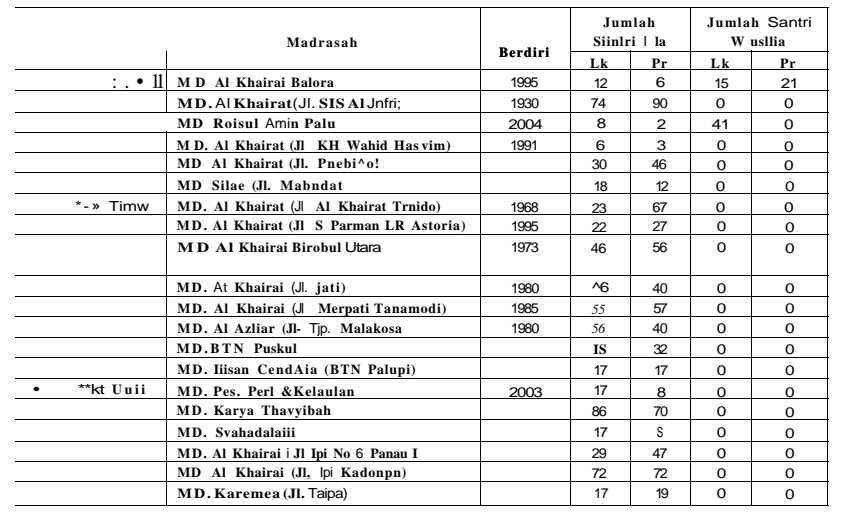

Sumber Data: Kementerian Agama Kota Palu 2010

\section{Kebijakan Kementerian Agama Kota Palu Berkaitan Dengan Madrasah Diniyah}

\section{Pendistribusian Buku-buku Pegangan}

Salah satu wujud dari perhatian pemerintah terhadap perkembangan dari madrasah diniyah adalah pendistribusian buku-buku pegangan yang telah diterbitkan oleh Kementerian Agama. Pendistribusian buku-buku dilakukan dengan cara mengirimkan bukubuku tersebut ke madrasah diniyah-madrasah diniyah atau dengan cara menyurati kepala sekolah masingmasing. Di antara buku-buku tersebut adalah buku kurikulum diniyah takmiliyah, buku mata pelajaran aqidah akhlak, bahasa Arab, fiqih/ibadah yang kesemuanya merupakan terbitan Direktorat Pendidikan Diniyah dan Pondok Pesantren Depag PJ tahun 2007.

\section{Pembinaan}

Pembinaan yang dilakukan oleh pihak Kanwil Kementerian Agama Kota Palu belum menunjukkan* perhatian khusus terkait pembinaan pada madrasah diniyah, pembinaan yang dilakukan selama ini hanya melalui penyuluh-penyuluh agama baik penyuluh PNS maupun penyuluh honorer. Pembinaan yang biasa dilakukan di antaranya pembinaan terhadap pondok pesantren, majelis taklim, pengajianpengajian, dan lain-lain. Tugas-tugas penyuluh dilakukan berdasarkan wilayah kerja masing-masing penyuluh. Lewat penyuluh ini pernah sekali dilakukan sosialisasi buku-buku paket dan silabus madrasah diniyah. Intensitas pembinaan terkait madrasah diniyah ini masih sangat minim.

\section{Pemberian Insentif Bagi Guru-guru Honorer}

Pemberian insentif bagi guru-guru honorer oleh Kanwil Kementerian Agama Sulawesi Tengah untuk tahun 2010 diberikan kepada guru sebanyak 210 orang dan bantuan dari Kementerian Agama Pusat adalah 50 orang jadi total guru yang mendapat bantuan insentif tersebut adalah sebanyak 260 orang. Penerimaan bagi guru-guru honorer tersebut diterima persatu tahun. Pemberian insentif bagi guru-guru honorer tersebut diterima tidak secara rutin melainkan digilir, guru yang sudah mendapatkan tahun ini sudah tidak mendapatkan tahun berikutnya. 


\section{Karakteristik Responden}

Sebagai lokasi sasaran adalah masyarakat yang berada di sekitar Madrasah Diniyah Awaliyah Al Khaerat Palu, baik masyarakat sebagai orangtua siswa MDA maupun masyarakat yang tidak memiliki anak bersekolah di madrasah diniyah.

Berkaitan dengan karakteristik responden ada rujuh kategori yang diangkat melalui penelitian, di antaranya: usia responden, jenis pekerjaan, pendidikan terakhir, jenis pendidikan yang dilalui, jumlah madin di sekitar tempat tinggal responden, jumlah anak, jumlah anak yang disekolahkan di sekolah agama.

Masyarakat yang menjadi responden dalam penelitian ini berjumlah 100 orang, dari segi usia mereka adalah antara 20 sampai 70 tahun. Kelompok usia mayoritas adalah 31-40 tahun (35\%) dan yang paling sedikit adalah usia 61-70 tahun (6\%), usia 20-30 tahun dan 41-50 tahun masing-masing (25\%), dan usia 51 $60(11 \%)$

Pekerjaan yang digeluti responden cukup beragam untuk menyederhanakan pengkategoriannya dikelompokkan menjadi tiga kategori, yaitu yang bernuansa umum, kependidikan dan keagamaan. Responden yang ada umumnya menggeluti pekerjaan yang bernuansa umum $70 \%$, kependidikan $16 \%$, dan keagamaan $14 \%$.

Jenjang pendidikan responden, sebagian besar SMA (44\%), menyusul SI (33\%). Hanya sedikit SD tidak tamat SD (7\%), sedangkan SMP (16\%). Pada jenjang pendidikan tersebut sebagian besar pada sekolah umum yakni SD (62\%), SLTP (52\%), dan SMA $(40 \%)$.

Pendidikan terakhir dari 100 orang responden sangat bervariasi, yakni: tidak tamat SD 2 orang (2\%); tamat SD 6 orang $(6 \%)$, tamat SLTP 15 orang (15\%), tamat SLTA 44 orang $(44 \%)$, dan tamat perguruan tinggi 33 orang $(33 \%)$.

Pendidikan responden dari jenjang kejenjang, sebagian besar menempuhjalur pendidikan umum, selebihnyajalur pendidikan agama. padajenjang SD (98 responden), 62 orang $(63,26 \%)$ melalui jalur pendidikan umum dan 36 orang $(36,73 \%)$ melalui jalur pendidikan agama. Jenjang pendidikan SLTP (92 responden), jalur pendidikan umum 52 orang $(56,52 \%)$; jalur pendidikan agama 40 orang $(43,47 \%)$. Jenjang SLTA (77 responden), jalur pendidikan umum 40 orang $(51,94 \%)$ dan jalur pendidikan agama 37 orang $(48,05 \%)$. Padajenjang PT (33 responden), melalui jalur pendidikan umum 16 orang $(48,48 \%)$ dan jalur pendidikan agama 17 orang $(51,51 \%)$.

Persebaran majalah dinding (madin) di sekitar responden, menurut mereka antara 1 sampai 3 lembaga. Sebagian besar responden (87\%) menyatakan hanya 1 madrasah, $4 \%$ menyatakan 2 madrasah, dan $1 \%$ menyatakan 3 madrasah, bahkan terdapat $8 \%$ yang tidak mengetahui adanya madrasah diniyah di sekitar lingkungan tempat tinggal mereka.

Ada 78 responden yang memiliki anak antara 1 sampai 10 orang dengan jumlah anak 194 orang. Responden lainnya 22 orang tidak memiliki anak. Ke 78 responden yang memiliki anak 51 orang diantaranya $51 \%$ menyekolahkan anaknya di madrasah ibtidaiyah denganjumlah anak 117 dari 194 orang.

Data di atas menunjukkan bahwa responden sebagai orang tua, sebagian besar memiliki perhatian untuk menyekolahkan anaknya di Madrasah Ibtidaiyah. Bahkan ada seorang responden yang memiliki 10 orang anak, semuanya disekolahkan di Madrasah Ibtidaiyah. Pada jenjang Tsanawiyah, responden yang menyekolahkan anaknya di madrasah hanya 28 orang (28\%) dengan jumlah anak 49 orang. Pada jenjang Aliyah, hanya 17 orang (17\%) responden yang menyekolahkan anaknya di Madrasah Aliyah dengan jumlah anak 38 orang.

Kecenderungan responden (orang tua) siswa menyekolahkan anaknya pada tigajenjang madrasah di atas, dapat dilihat pada tabel 4 :

Tabel 4:

Distribusi Kecenderungan Responden (orang tua) yang Memiliki Anak dan Menyekolahkan Anaknya di Madrasah dan PT.

\begin{tabular}{|c|l|c|c|c|c|c|}
\hline \multirow{2}{*}{ NO } & \multirow{2}{*}{ Uraian } & \multirow{2}{*}{ Jumlah } & \multicolumn{3}{|c|}{ Jenjang Pendidik; } & \multirow{2}{*}{} \\
\cline { 4 - 6 } & & & MI & MTS & MA & \\
\hline 1 & $\begin{array}{l}\text { Responden } \\
\text { (orang tua) }\end{array}$ & 78 & 51 & 28 & 17 & \\
\hline 2 & Anak & 194 & 117 & 49 & 38 & \\
\hline
\end{tabular}

Sumber: Laporan Penelitian (diolah)

\section{Respon Masyarakat Terhadap Madrasah Diniyah}

Berkaitan dengan respon masyarakat, ada 4 variabel yang ditelusuri, yakni pengetahuan, sikap, 
- - par. perolehan pengetahuan responden tentang w n s a h diniyah. berkaitan masing-masing variabel

\section{1- Pfc«getahuan responden tentang madrasah}

variabel ini, ada 9 aspek yang

Masing-masing aspek ditanyakan 5 tingkat

- niwuliuan responden, yaitu: tidak tahu sama sekali, nfci. tahu. ragu-ragu, tahu, dan sangat tahu. Kedelapan - . - - iimaksud adalah:

7. aan madin

a: Pengetahuan responden terhadap aspek sangat tinggi $94 \%$ (tahu $58 \%$ dan sangat - $\quad$ t - ' selebihnya rendah $6 \%$ bahkan sangat $W M^{*} k \quad(5 \%)$

.'r.is madin

Pemahaman tentang jenis madin ada 3 jnacam, yaitu madrasah diniyah formal, madrasah diniyah MM formal, dan madrasah diniyah informal. -" --Par ? jenis madin tersebut responden belum ami dengan baik ( $57 \%$ ), hanya $43 \%$ > yang $\sim$ ahaminya dengan baik.

C Jenjang madin

irasah diniyah formal memiliki jenjang pendidikan diniyah dasar, pendidikan diniyah

.-'.:-v:a. dan madrasah diniyah menengah. Sedangkan madrasah diniyah non formal mencakup diniyah tabniliyah awaliyah, diniyah takmiliyah wstha. dan diniyah takmiliyah ulya, pendidikan Alquran. majelis taklim, dan pengajian kitab.

Di lokasi penelitian, tidak diketemukan madin for- al. kecuali hanya madin non formal yakni madin takmiliyah. Jenjang madin yang dikelola masyarakat hanya tingkat "awaliyah". Karena itu, madin g ada oleh pengelola disebut MDA (Madrasah Diniyah Awaliyah).

Pengetahuan responden terhadap jenjang madin ".ersebut, sebagian besar telah mengetahuinya $\mathbf{1 8 1 \% )}$, namun masih ada $19 \%$ responden yang um memiliki informasi lengkap.

I Peluang penegerian madin

Madin secara esensial telah lama dikenal masyarakat di lokasi penelitian, ada yang mengenal dengan sebutan "sekolah Arab" ada pula yang menyebutnya "Ibtidaiyah sore", bahkan ada yang menyebutnya "sekolah pengajian". Tampaknya sebutan "madin" belum terlalu familiar dikalangan masyarakat.

Walaupun demikian, pemahaman masyarakat tentang pengertian madin, memiliki kecenderungan yang baik, seperti yang tergambar dari pernyataan responden, terdapat $73 \%$ yang menyatakan mengetahui. Akan tetapi masih ada $27 \%$ responden yang kurang bahkan belum memahami indikasi tersebut, ini mengisyaratkan besarnya harapan masyarakat terhadap pemerintah untuk memberi perhatian dalam pembinaan dan pengembangan madin.

e. Kurikulum madin

Kurikulum madin di lokasi penelitian ada dua macam yakni kurikulum Kementerian Agama dan kurikulum produk madin bersangkutan. Pada madin Al Khairat, kurikulum yang dominan digunakan adalah yang disusun oleh Al Khairat sendiri. Sedangkan madin yang bukan binaan Al Khairat dominan menggunakan kurikulum Kementerian Agama.

Pengetahuan responden tentang kurikulum madin dominan belum mengetahuinya $(57 \%)$, hanya sedikit respon yang mengetahuinya (22\%). Bahkan pengelola madin masih ada yang belum mengetahui kurikulum madin yang terakhir yakni kurikulum madin takmiliyah yang diterbitkan tahun 2007.

f. Madin non formal

Pemahaman responden tentang eksistensi madin secara kelembagaan, telah dipahami oleh hampir seluruh responden (98\%) menyatakan tahu bahkan sangat tahu. Tingginya pengetahuan responden tersebut, paling tidak didukung oleh 2 faktor, yaitu:

lembaga semacam madin telah lama dikenal oleh masyarakat dengan nama berbedabeda.

Kegiatan yang dilakukan di madin, telah banyak lembaga lain yang melakukan hal serupa seperti pada majelis taklim, pengajian kitab/Alquran.

g. Tujuan madin

Salah satu bentuk madin non formal adalah diniyah takmiliyah. Salah satu tujuannya adalah melengkapi pendidikan agama Islam (PAI) pada SD/MI, SMP/ MTS, dan SMA/MA, dalam rangka peningkatan keimanan dan ketakwaan siswa pada Allah Swt. 
Tujuan tersebut, telah dipahami dengan baik oleh $87 \%$ responden, selebihnya $13 \%$ masih belum memahami.

h. Keberjenjangan madin non formal

Di kalangan responden, pada satu sisi ada yang memahami bahwa madin non formal tidak perlu berjenjang. Lebih dari separuh di antara mereka (53\%) memahami tentang hal tersebut dan $47 \%$ lainnya kurang memahami bahkan tidak memahami.

Perbedaan responden dalam menyikapi keberjenjangan madin, tampaknya tidak terlepas dari realitas di lapangan karena madin yang ada di lokasi penelitian hanya MDA (Madrasah Diniyah Awaliyah), meskipun dalam regulasi yang ada telah memberi peluang untukjenjang wustha dan ulya.

\section{i. STTB madin}

Perolehan STTB ataupun pemanfaatannya untuk dapat dijadikan dasar melanjufkan kejenjang pendidikan berikutnya, sedikit sekali responden yang mengetahuinya (11\%) saja. Selebihnya (89\%) tidak tahu bahkan dominan tidak tahu sama sekali, sehingga memerlukan upaya ekstra dalam sosialisasinya.

Pemahaman responden terhadap 4 aspek yang ditanyakan, dengan tingkat pemahaman mereka terhadapanya, dapat dilihat pada tabel 5 .

Tabel 5.

Tingkat Pengetahuan Responden Terhadap Madin Menurut Aspek yang Diamati

\begin{tabular}{|c|l|c|c|c|c|c|}
\hline \multirow{2}{*}{ NO } & \multirow{2}{*}{ Aspek Pengetahuan } & \multicolumn{5}{|c|}{ Tingkat Pengetahuan } \\
\cline { 2 - 7 } & & TTSS & TT & RG & Tahun & S.I \\
\hline 1 & Tujuan madin & $1 \%$ & $4 \%$ & $1 \%$ & $58 \%$ & $i$ \\
\hline 2 & Jenis madin & $4 \%$ & $31 \%$ & $22 \%$ & $28 \%$ & 1 \\
\hline 3 & Jenjang madin & $2 \%$ & $8 \%$ & $9 \%$ & $51 \%$ & - \\
\hline 4 & Madin negeri & $3 \%$ & $10 \%$ & $14 \%$ & $57 \%$ & 1 \\
\hline 5 & Kurikulum madin & $10 \%$ & $47 \%>$ & $21 \%$ & $19 \%$ & \\
\hline 6 & Madin non formal & $1 \%$ & $1 \%$ & $0 \%$ & $40 \%$ & c \\
\hline 7 & Madin takmiliyah & $0 \%$ & $2 \%$ & $11 \%$ & $69 \%$ & 1 \\
\hline 8 & $\begin{array}{l}\text { Madin non formal } \\
\text { tidak berjenjang }\end{array}$ & $3 \%$ & $18 \%$ & $26 \%$ & $45 \%$ & \\
\hline 9 & $\begin{array}{l}\text { Madin non formal } \\
\text { berjenjang }\end{array}$ & $29 \%$ & $15 \%$ & $21 \%$ & $8 \%$ & \\
\hline 10 & $\begin{array}{l}\text { STT B Madin } \\
\text { nTyyyyy}\end{array}$ & $81 \%$ & $2 \%$ & $6 \%$ & $7 \%$ & \\
\hline
\end{tabular}

Sumber: Laporan Penelitian (diolah)

\section{Sikap responden terhadap madrasah diniyah}

Sikap responden adalah kesediaan responden untuk menerima, memberikan tanggapan terlibat aktif terhadap objek respon. Terhadap variabel ini, ada lima aspek yang diajukan kepada responden untuk disikapi, kelima aspek tersebut adalah: kesediaan menerima kehadiran madin di sekitar responden, kesediaan menghadiri dan berpartisipasi dalam diskusi tentang madin, kesediaan menerima hasil rancangan pengembangan madin, kesediaan untuk terlibat dalam mengelola madin, dan kesediaan untuk mencurahkan waktu sepenuhnya dalam mengembangkan madin.

Tingkat kesediaan responden terhadap lima aspek tersebut merupakan pencerminan sikap terhadap madin, bervariasi:

Pada aspek penerimaan kehadiran madin di lingkungan responden, cukup responsive karena lebih separuh (57\%) responden yang secara eksplisit mendambakannya. Selebihnya (43\%) ada yang ragu (18\%) dan ada responden yang tidak mengharapkannya $(25 \%)$.

Pada aspek kesediaan responden mengikuti diskusi tentang madin, ada yang memiliki tingkat kesediaan yang tinggi (49\%), adajuga rendah $(25 \%)$, bahkan ada responden yang masih bimbang (26\%).

Pada aspek penerimaan responden terhadap pengembangan madin, baik yang bersangkutan ikut dalam pembahasan maupun tidak, tingkat penerimaan mereka beragam. Sikap kooperatif itu dinyatakan oleh (52\%) responden. Di antara mereka masih ada $27 \%$ responden yang belum kooperatif. Sedangkan $21 \%$ lainnya masih belum jelas pendiriannya. Terhadap pernyataan sikap responden di atas dapat dimaknai bahwa masyarakat di lokasi penelitian sebagian besar bersedia diajak bersama dalam pengembangan madin.

Pada aspek kesediaan dalam mengelola madin, tingkat kesediaan responden cukup tinggi (74\%), hanya sedikit responden ( $5 \%$ ) yang rendah tingkat kesediaannya. Namun terdapat $21 \%$ responden belum percaya diri untuk mengelola madin.

Pada aspek kesiapan responden mencurahkan perhatian secara penuh terhadap pembinaan madin, sebagian besar (60\%) responden masih enggan mengurusinya secarafull time, hanya sedikit yang bersedia $(16 \%)$, dan terdapat $24 \%$ responden yang tingkat kesediaannya belum jelas. Data tersebut mengindikasikan bahwa masyarakat belum melihat madin sebagai pilihan pengabdian yang prospektif, 
- . ;an masih belum fokusnyapembinaan yang aiarnAan oleh pemerintah daerah dan Kementerian -. a setempat.

- -"".-iasi penyikapan responden terhadap lima

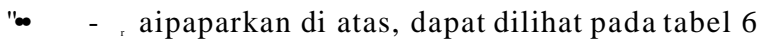

Tabel 6.

Pernyataan Sikap Responden Terhadap Jin Menurut Aspek Sikap Mereka

\begin{tabular}{|c|c|c|c|c|c|c|}
\hline \multirow{2}{*}{$" \cdot \mathbf{D} 1$} & \multirow{2}{*}{ Aspek Sikap } & \multicolumn{5}{|c|}{ Tingkat Sikap Responden } \\
\hline & & TTSS & T T & R G & Tahun & S.Tahun \\
\hline & $"$ ": • madin & $2 \%$ & $23 \%$ & $18 \%$ & $42 \%$ & $15 \%$ \\
\hline \multirow{2}{*}{\multicolumn{2}{|c|}{ V-rscCiin ikut }} & TBSS & Т В & R G & B & SB \\
\hline & & $7 \%$ & $18 \%$ & $26 \%$ & $38 \%$ & $11 \%$ \\
\hline & 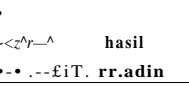 & $5 \%$ & $22 \%$ & $21 \%$ & $42 \%$ & $10 \%$ \\
\hline \multicolumn{2}{|r|}{$-::_{\text {_ }}$ mad in } & $1 \%$ & $4 \%$ & $21 \%$ & $58 \%$ & $16 \%$ \\
\hline \multicolumn{2}{|c|}{ 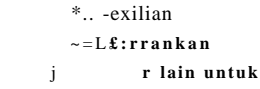 } & $50 \%$ & $10 \%$ & $24 \%$ & $12 \%$ & $4 \%$ \\
\hline
\end{tabular}

Saaaber: Laporan Penelitian (diolah)

3. Perilaku responden terhadap madrasah diniyah

Perijaku responden adalah aksi nyata yang di-

- ar responden dalam meresponi keberadaan dan ibangan madin. Padavariabel ini ada lima aspek

"" $\quad$ : asi responden yang dikaji, yaitu: jumlah anak ekolahkan di madin, jumlah keluarga yang keterlibatan dalam diskusi, pengelolaan, dan .. a n g a madin.

Keterlibatan responden dalam pembelajaran di _; .;:iganmemasukkananakmerekamenjadi siswa, jkkan partisipasi yang tinggi $(98 \%)$ responden mg menyekolahkan anaknya di madin. Anak yang mereka sekolahkan antara 1 sampai 5 orang, bahkan ada yang menyekolahkan semua anaknya di madin. Yang ra ng banyak adalah 1 orang $(37 \%)$ dan 4 sampai 5 ' -" _ anak (33\%). Tingginya animo respondenmenye-

-.an anaknya di madin di lokasi penelitian, perlu

---ooni secara positif oleh pengelola madin dan vementerian Agama setempat.

Perhatian responden terhadap madin, tidak hanya :ercermin dari respon menyekolahkan anaknya di -^adin. tetapijuga mengajak tetangga dan keluarga lain - enyekolahkan anaknya di madin. Partisipasi itu enunjukkan kepedulian yang tinggi (93\%) responden elakukannya. Mereka mengajak antara satu keluarga
(32\%) responden sampai lima keluarga (36\%) responden melakukannnya. Ada yang mengajak 2 sampai 3 keluarga (22\%), bahkan ada yang mengajak lebih dari 5 keluarga $(7 \%)$.

Pada aspek pengembangan madin yang dibangun melalui diskusi untuk pencarian ide dan strategi, tingkat partisipasi responden juga tinggi (96\%), yang sering mengikuti diskusi (72\%) dan selalu (24\%).

Bentuk partisipasi lainnya yang ditunjukkan responden dalam pengembangan madin adalah keterlibatan dalam pengelolaan. Terdapat $64 \%$ responden yang mengaku terlibat dalam pengelolaan madin. Keterlibatan mereka ada yang mencapai 1-5 tahun (26\%), 5 tahun ke atas (16\%) dan hanya 1 bulan (22\%). Responden lainnnya ( $36 \%$ ) yang belum mengambil peran dalam pengelolaan madin.

Pengelolaan madin memerlukan kreativitas tersendiri, terutama membuat rancang bangun sebuah madin yang prospektif, sehingga madin tidak hanya sebagai lembaga pem-back-up pengajaran agama pada lembaga persekolahan jenjang dasar menengah, tetapi sebuah pilihan bukan pelarian. Keterlibatan responden pada aspek rancangan tersebut, menunjukkan partisipasi rendah hanya $23 \%$ responden yang melakukan kreasi. Selebihnya (77\%) responden yang belum mengambil peran walaupun sebagian besar dari mereka telah terlibat sebagai pengelola madin.

Distribusi partisipasi yang mencerminkan prilaku responden terhadap madin, dapat dilihat pada tabel 7.

Tabel 7.

Tingkat Partisipasi Responden Terhadap Madin Menurut Jenisnya

\begin{tabular}{|c|c|c|c|c|c|c|}
\hline \multirow{2}{*}{ No } & \multirow{2}{*}{ Jenis partisipasi } & \multicolumn{5}{|c|}{ Tingkat Partisipasi Responden } \\
\hline & & $\begin{array}{c}\text { Semua } \\
\text { Anak }\end{array}$ & 4-5 org & $2-3$ org & 1 orang & Tidak ada \\
\hline 1 & $\begin{array}{l}\text { Jumlah anak yang } \\
\text { disekolahkan di } \\
\text { madin }\end{array}$ & $69 \mathrm{c}$ & & $22 *$ & $37 *$ & 2* \\
\hline 2 & $\begin{array}{l}\text { Jumlah keluarga } \\
\text { yang diajak }\end{array}$ & $79 \mathrm{f}$ & $36^{*}$ & $22 *$ & $32 *$ & 3* \\
\hline \multirow{2}{*}{3} & \multirow{2}{*}{$\begin{array}{l}\text { Keterlibatan dalam } \\
\text { diskusi }\end{array}$} & Selalu & sering & jarang & $\begin{array}{l}\text { Satu } \\
\text { kali }\end{array}$ & Tidak pernah \\
\hline & & $24 *$ & $72^{*}$ & $2 *$ & $1^{*}$ & $1^{*}$ \\
\hline \multirow{2}{*}{4} & \multirow{2}{*}{$\begin{array}{l}\text { Keterlibatan dalam } \\
\text { merancang }\end{array}$} & Selalu & sering & jarang & $\begin{array}{l}\text { Satu } \\
\text { kali }\end{array}$ & Tidak pernah \\
\hline & & 0* & 9* & $7 *$ & $7^{*}$ & $77 \%$ \\
\hline \multirow[t]{2}{*}{5} & \multirow{2}{*}{$\begin{array}{l}\text { Keterlibatan dalam } \\
\text { pengelolaan }\end{array}$} & $\begin{array}{c}\text { Di atas } 5 \\
\text { thn }\end{array}$ & $2-5$ thn & setahun & Sebulan & Tidak pernah \\
\hline & & $16 *$ & $5 *$ & $21^{*}$ & $22 *$ & $36 *$ \\
\hline
\end{tabular}

Sumber: Laporan Penelitian (diolah) 


\section{Perolehan pengetahuan responden tentang madrasah diniyah}

Informasi tentang madin pada responden, mereka memperoleh dari berbagai sumber. Ada empat sumber perolehan informasi madin pada responden. Keempat sumber tersebut adalah, media massa, lingkungan madin, program pemerintah, dan sumber lain. Tingkat penerimaan responden dari masing-masing sumber bervariasi.

Informasi melalui media massa, intensitasnya dirasakan kurang optimal oleh $53 \%$ responden, selebihnya $47 \%$ responden merasakan adanya optimalisasi sehingga membentuk pemahaman mereka tentang madin. Bahkan $18 \%$ di antaranya merasakan sangat optimal.

Selain aspek media massa, informasi madin pada masyarakat juga dilakukan oleh pengelola madin. Intensitas informasi dirasakan oleh $58 \%$ responden. Dari jumlah tersebut $32 \%$ di antaranya merasakan adanya optimalisasi dari pengelola sehingga membentuk pemahaman yang optimal pula. Namun masih ada $42 \%$ responden merasakan belum optimalnya informasi yang dilakukan pengelola madin.

Sumber informasi tidak kalah pentingnya adalah pemerintah. Sosialisasi program pemerintah yang dilakukan oleh Kementerian Agama tentang madin, dirasakan belum optimal oleh $60 \%$ responden. Baru $40 \%$ responden yang merasakan adanya optimalisasi informasi dari Kementerian Agama, itupun baru $20 \%$ yang sangat merasakan, sehingga berpengaruh pada tingkat pengetahuan mereka. Realitas ini memang didukung oleh data lapangan yang menunjukkan bahwa pembinaan madin oleh Kementerian Agama belum focus dan belum komprehensif.

Akumulasi sumber informasi pengetahuan dan tingkat perolehannya yang dirasakan oleh responden pada aspe-aspek di atas, dapat dilihat pada tabel 8 .

Tabel 8.

Tingkat Perolehan Pengetahuan Responden Menurut Sumbernya

\begin{tabular}{|c|c|c|c|c|c|}
\hline \multirow[b]{2}{*}{ No } & \multirow{2}{*}{$\begin{array}{c}\text { Sumber } \\
\text { Pengetahuan } \\
\text { Responden }\end{array}$} & \multicolumn{4}{|c|}{ Tingkat Pengetahuan Responden } \\
\hline & & $\begin{array}{c}\text { Tidak } \\
\text { sama } \\
\text { sekali }\end{array}$ & $\begin{array}{l}\text { Minim } \\
\text { sekali }\end{array}$ & $\begin{array}{c}\text { Separuh } \\
\text { dari } \\
\text { pengetahuan }\end{array}$ & $\begin{array}{c}\mathrm{M} \text { ayoritas } \\
\text { pengetahuan }\end{array}$ \\
\hline 1 & Media massa & $269 \mathrm{i}$ & 277 & $29 ', !$ & $137 \mathrm{r}$ \\
\hline 2 & $\begin{array}{l}\text { Lingkungan } \\
\text { madin }\end{array}$ & 18'; & $2 V I$, & $\left.26^{\prime}\right\}$ & \\
\hline 3 & $\begin{array}{l}\text { Program } \\
\text { pemerintah }\end{array}$ & $37 ; ; ;$ & $23, i$ & $20 / \mathrm{r}$ & 141 \\
\hline
\end{tabular}

Sumber: Laporan Penelitian (diolah)
Analisis Inferensial terhadap Variabel-variabel yang Mempengaruhi Respon Masyarakat terhadap Madarasah Diniyah.

\section{a. Analisis Korelasi Antara Identitas Res. ponden}

Sesuai dengan tujuan penelitian, bahwa analisis imperensial dilakukan untuk mengetahui keeratan hubungan antara variabel (variabel dependen dan independen) yang telah ditentukan sebelumnya. Variabel independen yang akan dianalisis adalah: tingkat usia, perbedaanjenis pekerjaan (yakni yang berkaitan dengan pemerintahan dan perekonomian; berkaitan dengan kependidikan dan berkaitan dengan keagamaan), tingkat pendidikan, dan perbedaan latar belakang jenis pendidikan (sekolah umum dan agama).

Jenis analisis yang digunakan adalah analisis korelasi parsial dan korelasi ganda pada setiap variabel. Alat analisis menggunakan komputer melalui program SPSS. Analisis korelasi parsial dilakukan untuk menguji keeratan hubungan antara satu variabel karakterisitik responden dengan tingkat respon responden terhadap madrasah diniyah. Tingkat respon yang dimaksud adalah gabungan antarajumlah skor pengetahuan, sikap dan perilaku responden terhadap madrasah diniyah.

Hasil analisis kedua variabel dimaksud dapat dilihat pada tabel 9 .

Tabel 9.

Hasil Analisis Korelasi Parsial dan Korelasi Ganda

\begin{tabular}{|c|c|c|c|c|c|}
\hline No & $\mathbf{x}$ & $\mathbf{Y}$ & $\mathbf{R}$ & $a=0.050$ & Keteransan \\
\hline I & Usia & \multirow{4}{*}{ Respon } & 0.091 & 0,370 & $\begin{array}{l}\text { Tidakberkorelasi dengan } \\
\text { signifikansi rendah }\end{array}$ \\
\hline 2 & Jenis Pekerjaan & & 0.274 & 0,006 & $\begin{array}{l}\text { Berkorelasi kuat dengan } \\
\text { signifikansi tingai }\end{array}$ \\
\hline 3 & Pendidikan Terakhir & & 0,185 & 0,068 & $\begin{array}{l}\text { Tida k berkorelas } i \text { deng an } \\
\text { signifikansi rendah }\end{array}$ \\
\hline 4 & Jenis Pendidikan & & 0.248 & 0.016 & $\begin{array}{l}\text { Berkorelasi kual dengan } \\
\text { signifikansi tinggi }\end{array}$ \\
\hline 5 & Usia jenis pekerjaan & \multirow{10}{*}{ Respon } & 0.292 & 0.013 & $\begin{array}{l}\text { Berkorelasi kuat dengan } \\
\text { sisntlikansi tim }><\mathrm{ri}\end{array}$ \\
\hline 6 & Usia. Pendidikan Terakhir & & 0.228 & 0,079 & $\begin{array}{l}\text { Tidak berkorelasi dengan } \\
\text { signifikansi rendah }\end{array}$ \\
\hline 7 & Usia.Jenis Pendidikan & & 0.267 & 0,033 & $\begin{array}{l}\text { Berkorelasi kuat dengan } \\
\text { signifikansi tinggi }\end{array}$ \\
\hline 8 & $\begin{array}{l}\text { Pendidikan Terakhir. Jenis } \\
\text { Pekeriaan }\end{array}$ & & 0,275 & 0,024 & $\begin{array}{l}\text { Berkorelasi kuat dengan } \\
\text { signifikansi tinggi }\end{array}$ \\
\hline 9 & $\begin{array}{l}\text { Jenis Pendidikan, Jenis } \\
\text { Pekerjaan }\end{array}$ & & 0.295 & 0.015 & $\begin{array}{l}\text { Berkorelasi kuat dengan } \\
\text { sianifikansi lintisi }\end{array}$ \\
\hline 10 & $\begin{array}{l}\text { Jennis Pendidikan; Pendidikan } \\
\text { Terakhir }\end{array}$ & & 0.246 & 0.060 & $\begin{array}{l}\text { Tidabberkorelasi dengan } \\
\text { signifikansi rendah }\end{array}$ \\
\hline 11 & $\begin{array}{l}\text { Pendidikan Terakhir, Usia } \\
\text { Jenis Pekerjaan }\end{array}$ & & 0.299 & $0.03 !$ & $\begin{array}{l}\text { Berkorelasi kuat dengan } \\
\text { signifikansi tinggi }\end{array}$ \\
\hline 12 & $\begin{array}{l}\text { Jenis Pendidikan. Usia. Jenis } \\
\text { Pekeriaan }\end{array}$ & & 0.313 & 0.024 & $\begin{array}{l}\text { Berkorelasi kuat dengan } \\
\text { signifikansi tinggi }\end{array}$ \\
\hline 13 & $\begin{array}{l}\text { Jenis Pendidikan, Pendidikan } \\
\text { Terakhir. Jenis Pekerjaan }\end{array}$ & & 0.292 & 0.046 & $\begin{array}{l}\text { Berkorelasi kuat dengan } \\
\text { sisniiikansi tingei }\end{array}$ \\
\hline 14 & $\begin{array}{l}\text { Jenis Pendidikan, Usia, Jenis } \\
\text { Pekerjaan. Pendidikan } \\
\text { Terakhir }\end{array}$ & & $0.312 "$ & 0.058 & $\begin{array}{l}\text { Tidak berkorelasi dengan } \\
\text { signifikansi rendah }\end{array}$ \\
\hline
\end{tabular}

Jurnal "Al-Qalam" Volume 17 Nomor 1 Januari - Juni 2011 
Hasil analisis parsial terhadap 4 variabel (1 aajni 4) diperoleh hasil bahwa terdapat 2 variabel $\mathbf{3}$ «Bf]beikorelasi kuat dengan signifikasi tinggi dan 2 -" -". >ang tidak berkoreiasi dengan signifikasi

--' ini menunjukkan bahwa usia dan pcadidikan terakhir tidak berpengaruh terhadap ' " -..•> arakat terhadap madrasah diniyah sesaeniara jenis pekerjaan dan jenis pendidikan hup f.rtruh terhadap respon yang diberikan oleh -. :;rhadap madrasah diniyah.

Hasil analisis korelasi ganda terhadap 10 variabel tabei tersebut (5 sampai 14) terdapat 7 variabel vMgaacmpum ai tingkat korelasi yang kuat dan 3 variabel

- -.• "-erkorelasi kuat pada taraf signifikansi 0,05

- nunj ukkan bahwa tingkat penerimaan responden

Madrasah Diniyah cukup tinggi dengan -napretasi bahwa usia, jenis pendidikan, tingkat pr»idaVan serta jenis pekerjaan mempengaruhi tingkat xsfian masyarakat terhadap Madrasah Diniyah.

\section{Inalisis Korelasi Antara Respon Responden} Terhadap Madrasah Diniyah

Beberapa variabel dependen yang berhubungan Jcaean respon responden yakni: tingkat pengetahuan, - - : sipasipasif), perilaku(partisipasiaktif), dan ^ gkat respon responden terhadap madrasah diniyah. Basil analisis korelasi parsial dan korelasi ganda variabel dependen terhadap masing-masing indikator iapatdilihat pada tabel 10 .

Tabel 10.

Analisis Korelasi Respon Responden Terhadap Madrasah Diniyah

\begin{tabular}{|c|c|c|c|c|}
\hline & $\mathbf{Y}$ & $\mathbf{R}$ & $a=0,050$ & \\
\hline & $\begin{array}{l}\text { Jumlah Anak yg Di } \\
\text { Sekolahkan Madin }\end{array}$ & 0.246 & \multirow{2}{*}{$\begin{array}{l}\mathbf{0 , 0 1 4} \\
0,000\end{array}$} & \multirow{5}{*}{$\begin{array}{l}\text { Berkotererangan } \\
\text { signifikansi kuat dengan tinggi } \\
\text { Berkoreiasi kuat dengan } \\
\text { signifikansi tinggi } \\
\text { Berkoreiasi kuat dengan } \\
\text { signifikansi tinggi } \\
\text { Berkoriasi kuat dengan } \\
\text { signifikansi tinggi } \\
\text { Berkoreiasi kuat dengan } \\
\text { signifikansi tinggi }\end{array}$} \\
\hline & $\begin{array}{l}\text { Jumlah Diajak ke } \\
\text { Ma din }\end{array}$ & 0,357 & & \\
\hline & Keterlibatan Diskusi & 0.546 & 0.000 & \\
\hline & Keterlibatan Mengelola & 0,204 & \multirow[t]{2}{*}{0,042} & \\
\hline & Keterlibatan Merancang & 0,354 & & \\
\hline & $\begin{array}{l}\text { Jumlah Anak yg Di } \\
\text { Sekolahkan Madin }\end{array}$ & 0,242 & \multirow{2}{*}{$\begin{array}{l}0,004 \\
0,001\end{array}$} & \multirow{10}{*}{ 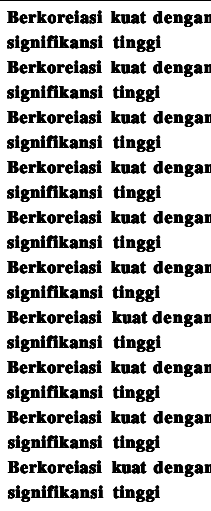 } \\
\hline & $\begin{array}{l}\text { Jumlah Diajak ke } \\
\text { Madin }\end{array}$ & 0.338 & & \\
\hline & Keterlibatan Diskusi & 0.342 & 0.000 & \\
\hline & Keterlibatan Mengelola & 0,220 & \multirow{2}{*}{$\begin{array}{l}0,028 \\
0.001\end{array}$} & \\
\hline & Keterlibatan Merancang & 0.319 & & \\
\hline \multirow{5}{*}{$\begin{array}{c}1 \text { PiBfii ilai in } \\
\text { Sikap }\end{array}$} & $\begin{array}{l}\text { Jumlah AnakygDi } \\
\text { Sekolahkan Madin }\end{array}$ & 0.329 & \multirow{5}{*}{\begin{tabular}{l|}
0,004 \\
0.000 \\
0.000 \\
0.031 \\
0.000
\end{tabular}} & \\
\hline & $\begin{array}{l}\text { Jumlah Diajak ke } \\
\text { Madin }\end{array}$ & 0.431 & & \\
\hline & Keterlibatan Diskusi & 0.577 & & \\
\hline & Keterlibatan Mengelola & 0,263 & & \\
\hline & Keterlibatan Merancang & 0.418 & & \\
\hline
\end{tabular}

Tabel 10 dalam menganalisis variabel $\mathrm{x}$ menggunakan analisis korelasi dengan sistem SPSS, variabel pengetahuan (variabel $x$ ) yang dihubungkan dengan variabel y di antaranya (jumlah anak yang disekolahkan di madin, jumlah anak yang diajak ke madin, keterlibatan dalam diskusi, keterlibatan dalam mengelola, dan keterlibatan dalam merancang) semuanya berkoreiasi kuat dengan signifikansi tinggi. Hal ini menunjukkan bahwa pengetahuan responden tentang madrasah diniyah sangat berpengaruh pada madrasah diniyah.

Variabel sikap (variabel $\mathrm{x}$ ) yang dihubungkan dengan variabel y, diantaranya: jumlah anak yang disekolahkan di madin, keterlibatan dalam diskusi, keterlibatan dalam mengelola, dan keterlibatan dalam merancang) semuanya berkoreiasi kuat dengan signifikansi tinggi dengan taraf kepercayaaan ( $\mathrm{a}=0.05)$. Hal ini menunjukkan bahwa sikap responden tentang madrasah diniyah sangat berpengaruh pada madrasah diniyah.

Variabel pengetahuan dan sikap (variabel $\mathrm{x}$ ) yang dihubungkan dengan variabel y, diantaranya: jumlah anak yang disekolahkan di madin, keterlibatan dalam diskusi, keterlibatan dalam mengelola, dan keterlibatan dalam merancang) semuanya berkoreiasi kuat dengan signifikasi tinggi dengan taraf kepercayaaan $(\mathrm{a}=0.05)$. Hal ini menunjukkan bahwa pengetahuan dan sikap responden tentang madrasah diniyah sangat berpengaruh pada madrasah diniyah.

c. Analisis Korelasi Parsial dan Korelasi Ganda Antara Pengetahuan dan sikap terhadap perilaku Responden.

Tabel 11

Hasil Analisis Korelasi Parsial dan Korelasi Ganda Antara Pengetahuan dan Sikap Terhadap Perilaku Responden

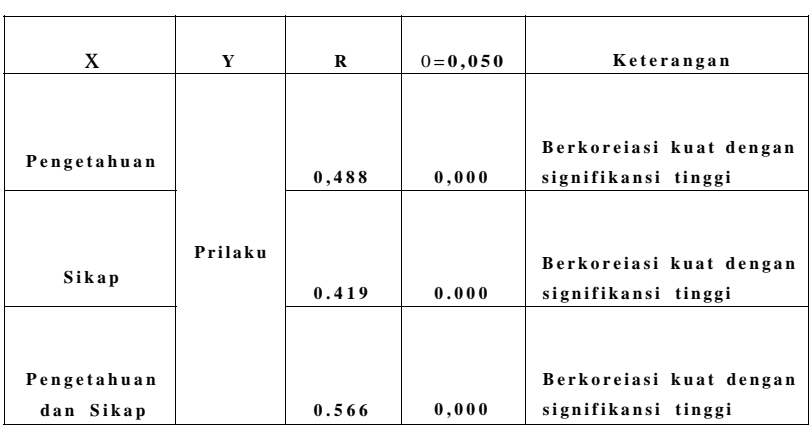

Hasil analisis dari tabel dengan variabel $x$ yaitu pengetahuan, sikap dan pengetahuan dan sikap yang dihubungkan dengan variabel y prilaku responden menunjukkan bahwa semuanya berkoreiasi kuat 
dengan signifikasi tinggi dengan taraf kepercayaaan $(\mathrm{a}=0.05)$. Hal ini menunjukkan bahwa pengetahuan, sikap, dan pengetahuan dan sikap responden tentang madrasah diniyah sangat berpengaruh pada madrasah diniyah.

\section{PENUTUP}

\section{Kesimpulan}

1. Berdasarkan data lapangan yang diperoleh bahwa persebaran madrasah diniyah baik tingkat Sulawesi Tengah maupun kota Palu cukup menggembirakan, hal ini menunjukkan bahwa masyarakat memiliki respon positif terhadap madrasah diniyah. Respon tersebut dapat dipengaruhi oleh banyak hal. Pada penelitian ini respon masyarakat yang diamati adalah berkaitan pada penyelenggara madrasah diniyah, yaitu: pengetahuan, sikap, dan perilaku masyarakat. Hasil analisis data yang dilakukan diperoleh bahwa tingkat pengetahuan responden terhadap madrasah diniyah dominan mengetahui kecuali pada beberapa aspek seperti pada aspek kurikulum, jenjang madin, dan STTB. Pada aspek sikap responden terhadap madarsah diniyah menunjukkan perhatian yang tinggi kecuali pada hal penyediaan waktu secara penuh untuk mengelola madin. Dan pada aspek perilaku responden terhadap madrasah diniyah menunjukkan partispasi yang sangat tinggi kecuali dalam hal keterlibatan dalam merancang madin. Hal itu kemungkinan disebabkan oleh keterbatasan kemampuan dan keterampilan responden.

2. Faktor yang mempengaruhi respon masyarakat terkait dengan sumber informasi yang mereka peroleh pada penelitian ini ada tiga sumber informasi utama yang dijadikan sasaran pengamatan yaitu media massa, lingkungan madin, dan program pemerintah. Dari ketiga sumber informasi tersebut yang dominan dirasakan oleh responden adalah dari lingkungan madin, sedangkan yang paling minim adalah dari program pemerintah.

\section{Rekomendasi}

1. Penyelenggaraan madarsah diniyah belum tersosialisasi dan terkoordinasi secara baik sehingga beberapa aspek yang sangat teknis pun belum dipahami oleh masyarakat seperti masalah kurikulum, penjenjangan, dan berkaitan dengan STTB. Oleh karena itu, diperlukan sosialisai yang lebih intens dan terkoordinasi antara Kementerian
Agama dengan pengelola madin dengan melibatkan tokoh agama dan tokoh masyarakat.

2. Kementerian Agama sebagai pembina madrasah diniyah perlu meningkatkan pembinaan dan pelayanan kepada madin sehingga dapat berkiprah lebih optimal dalam peningkatan pengetahuan, perilaku, dan wawasan keagamaan siswa terutama sjswa muslim di sekolah umum. Pengorganisasian pembinaan yang ada selama ini kurang menyentuh substansi madrasah diniyah. Penyuluh yang diharapkan melakukan pembinaan kurang optimal karena mereka lebih fokus pada majelis taklim, TPA, dan lain-lain. Kemudian pengawas madrasah juga tidak melakukan pembinaan secara khusus terhadap madin. Karena itu, perlu ditinjau ulang pola pembinaan madin oleh Kementerian Agama.

\section{Ucapan Terimakasih}

Keberadaan tulisan ini merupakan hasil dari masukan, tanggapan, dan diskusi dari rekan-rekan peneliti Balai Litbang Agama Makassar terkhusus kepada Kepala Balai Litbang Agama Makassar yang telah memberikan peluang dan motivasi kepada penulis dan kepada rekan-rekan bidang pendidikan, kami ucapkan terima kasih banyak. Ucapan terima kasih kami haturkanjuga kepada responden/informan kami yang telah membantu kami dalam memperoleh datadata ketika kami berada di lapangan.

\section{DAFTAR PUSTAKA}

Al Boneh, Abd. Azis. 2007. Studi Kompetensi Guru Madrasah Diniyah Ula di Kabupaten Agam Sumatera Barat. Jurnal Edukasi. Badan Litbang dan Diklat Depag RI. Volume 5 No. 4 Oktober - Desember 2007.

Arif, Mahmud. 2008. Pendidikan Islam Trasnformatif. Yogyakarta. LKiS

Direktorat Pendidikan Diniyah dan Pondok Pesantren. Direktorat Jenderal Pendidikan Islam. Dep. Agama RI. 2007. Pedoman Penyelengaraan Diniyah Takmiliyah.

Dirjen Kelembagaan Agama Islam, Direktorat Pendidikan Keagamaan dan Pondok Pesantren. Departemen Agama RI. 2004. Petunjuk Teknis Pondok Pesantren.

PP Nomor 25 Tahun 2007 tentang Pendidikan Agama dan Pendidikan Keagamaan.

http://id.vvikipedia.org/wiki/Respon.

http://id.vvikipedia.org/_viki/Teori_Belajar_Bhavioristik. 